KS. JERZY WITCZAK* - WROCŁAW

\title{
25 LAT KOMPUTERYZACJI BIBLIOTEK KOŚCIELNYCH W POLSCE - DOROBEK FEDERACJI FIDES
}

\section{Początki Federacji Bibliotek Kościelnych FIDES}

25 lat temu rozpoczęła się zorganizowana komputeryzacja bibliotek kościelnych w Polsce i zarazem powstała Federacja Bibliotek Kościelnych FIDES, powołana w tym celu. Dokonało się to dzięki jednemu człowiekowi - księdzu Krzysztofowi Gonetowi, przenikliwemu wizjonerowi i pasjonatowi zastosowania nowoczesnej techniki komputerowej do automatyzacji bibliotek. Z perspektywy historii ks. K. Gonet jawi się jako człowiek opatrznościowy na nowe czasy. Wyróżniający się absolwent Instytutu Bibliotekoznawstwa i Informacji Naukowej Uniwersytetu Warszawskiego z 1981 roku, po studiach rozpoczął pracę w Dziale Przetwarzania Danych Biblioteki Narodowej, jednak rok później wstąpił do Wyższego Metropolitalnego Seminarium Duchownego w Warszawie. Jego kontakty z pracownikami Biblioteki Narodowej i środowiskiem bibliotekarskim trwały nadal podczas studiów seminaryjnych, które ukończył w 1987 roku, i później, podczas pracy duszpasterskiej. Gdy zatem w 1989 roku został mianowany zastępcą dyrektora Biblioteki Wyższego Metropolitalnego Seminarium Duchownego w Warszawie, mógł natychmiast skorzystać ze swojej wiedzy i znajomości środowiska.

Był to czas, kiedy po 1989 roku zaczęły do Polski docierać coraz liczniej mikrokomputery, zwłaszcza komputery osobiste zgodne z IBM PC, i zaczęła się upowszechniać idea komputeryzacji bibliotek w oparciu o ten relatywnie tani sprzęt. W niektórych bibliotekach kościelnych podjęte zostały próby wykorzystania pojedynczych komputerów osobistych do tworzenia katalogowych baz danych bądź automatyzacji wydruku kart katalogowych. Również od 1989 roku Jerzy Swianiewicz i Jan Wierzbowski zaczęli tworzyć w Bibliotece Narodowej program MAK przeznaczony dla komputerów z systemem MS-DOS, a w 1990 roku pojawiła się jego wersja 1.0. Zarazem odzyskanie wolności pozwalało myśleć o tworzeniu nowych stowarzyszeń.

* Ks. Jerzy Witczak - dr filozofii, dyrektor Biblioteki Papieskiego Wydziału Teologicznego we Wrocławiu, e-mail: witczak@pwt.wroc.pl 
Sama historia powstania Federacji FIDES jest bardzo dobrze opisana ${ }^{1}$. Trzeba jednak podkreślić, co wyraźnie stwierdza ks. K. Gonet, że nie miało to być stowarzyszenie bibliotekarzy kościelnych, które nawiązywałoby do wcześniejszych prób utworzenia takiej ogólnopolskiej organizacji. Celem powołanej 23 września 1991 roku Federacji FIDES miała być:

koordynacja prac nad komputeryzacją prac bibliotecznych oraz dążenie do stworzenia komputerowej sieci bibliotek kościelnych².

$\mathrm{W}$ tej dziedzinie inicjator FIDES widział ciągłość z wcześniejszymi teoretycznymi rozważaniami, podjętymi na forum konferencji ABMK już w 1981 roku oraz w 1987 roku, a zwłaszcza z referatem Marii Wrocławskiej, wygłoszonym podczas tej drugiej sesjỉ ${ }^{3}$. Cytuje z niego słowa, które nawet i dziś są aktualne dla wielu zaniedbanych bibliotek kościelnych:

Komputeryzacja bibliotek jest warunkiem ich dalszego istnienia w społeczeństwie, ponieważ biblioteki niesprawnie działające, powoli dostarczające informacji bibliotecznych i bibliograficznych, staną się martwe, stracą czytelników, będą żyły tylko dla siebie ${ }^{4}$.

„Nowy etap prac nad komputeryzacją bibliotek kościelnych” - jak stwierdza ks. K. Gonet ${ }^{5}$, lub raczej: właściwa komputeryzacja sieci bibliotek kościelnych - rozpoczął się konferencją na ten temat, która odbyła się 24 czerwca 1991 roku w siedzibie Wyższego Metropolitalnego Seminarium Duchownego na Bielanach w Warszawie. Zwołana pod auspicjami kard. Franciszka Macharskiego jako przewodniczącego Komisji Episkopatu Polski ds. Nauki Katolickiej odniosła niebywały sukces, zgromadziła bowiem przedstawicieli 48 bibliotek kościelnych i łącznie 130 uczestników. Oprócz wystąpień zaproszonych gości, wśród których była m.in. Anna Paluszkiewicz, oraz pokazów sprzętu i oprogramowania dla bibliotek, najważniejszą część konferencji stanowiły komunikaty ośmiu bibliotek na temat ich doświadczeń z wykorzystaniem komputerów. W końcowej dyskusji wszyscy potwierdzili pilną konieczność rozpoczęcia prac nad jednolitym systemem komputerowym dla polskich bibliotek kościelnych. W tym celu postanowiono zwołać na 23 września 1991 roku naradę roboczą.

Ta narada „bibliotek wiodących” odbyła się również w Bibliotece WMSD w Warszawie na Bielanach. Uczestniczyło w niej trzynaście bibliotek z uczelni katolickich i wydziałów teologicznych oraz innych, mających już pewne osiągnięcia w dziedzinie komputeryzacji. W przyjętej przez uczestników deklaracji

\footnotetext{
${ }^{1}$ Por. zwłaszcza: K. Gonet, Komputeryzacja bibliotek i możliwości jej wplywu na procesy gromadzenia księgozbiorów w bibliotekach kościelnych: zarys problematyki, „Archiwa Biblioteki i Muzea Kościelne" (dalej: ABMK), 62 (1993) s. 255-268; M. Wójtowicz, Federacja Bibliotek Kościelnych FIDES w Polsce w latach 1991-2001: (10-lecie istnienia Federacji FIDES), „Fides. Biuletyn Bibliotek Kościelnych”, 16/17 (2003) z. 1/2 s. 21-72. Autor, pełniący funkcję przewodniczącego zarządu FIDES od 2001 roku, przy opracowaniu artykułu korzystał również z własnego archiwum oraz zebranych przez siebie danych statystycznych.

${ }^{2}$ Gonet, Komputeryzacja bibliotek, s. 260.

${ }^{3}$ M. Wrocławska, Możliwości komputeryzacji biblioteki, ABMK, 56 (1988) s. 147-156.

${ }^{4}$ Tamże, s. 147.

${ }^{5}$ Gonet, Komputeryzacja bibliotek, s. 257.
} 
stwierdzono zwłaszcza konieczność zachowania jednolitości formatu oraz przydatność jednolitości oprogramowania, z sugestią by był to program MAK. Wyraźnie mówi się też o zbudowaniu w przyszłości jednolitego systemu komputerowego i wspólnej bazy katalogowej. Ten wątek, jak i cała deklaracja, jest głównie dziełem ks. K. Goneta, który od początku widział potrzebę systemowych rozwiązań i integracji systemów bibliotecznych. Najważniejszym owocem narady było powołanie do istnienia Federacji Bibliotek Kościelnych FIDES.

Powołano również tymczasowe Biuro Federacji, którego przewodniczącym został ks. dr Tadeusz Stolz, zastępca dyrektora BU KUL, a siedzibą biura została Biblioteka Uniwersytecka KUL. Warto tu zauważyć, że w ten sposób biblioteki kościelne właściwie wyprzedziły działania bibliotek akademickich, bowiem ogólnopolska narada dyrektorów bibliotek szkół wyższych na temat „Komputeryzacja bibliotek" odbyła się we Wrocławiu dopiero 11-12 lutego 1992 roku.

Od momentu przyjęcia deklaracji założycielskiej federacji FIDES rozpoczęły się konkretne działania, które były podsumowywane podczas kolejnych dorocznych narad roboczych. Nabrały one również charakteru spotkań użytkowników programu MAK, połączone były z prezentacją nowości i rozwiązywaniem problemów. Pierwsze takie spotkanie, w którym wzięło udział już 21 bibliotek, odbyło się 30 września 1992 roku w Bibliotece Uniwersyteckiej KUL. Rok później druga narada robocza odbyła się również w Lublinie 8 maja 1993 roku. Do FIDES należały już wtedy 53 biblioteki. Dyskutowano o problemach tworzenia komputerowego katalogu centralnego bibliotek teologicznych w Polsce oraz nad wspólpracą przy tworzeniu komputerowej bibliografii piśmiennictwa kościelnego. Te dwa główne tematy będą się przewijać w różny sposób w działalności FIDES w następnych latach, jak również sprawa opracowania rzeczowego - utworzenia słownika słów kluczowych z teologii. W gościnnych murach Ośrodka Obliczeniowego Katolickiego Uniwersytetu Lubelskiego zorganizowano z kolei dwukrotnie szkolenie drugiego stopnia z programu MAK. Trzecia narada robocza FIDES miała miejsce 9 maja 1994 roku w WMSD w Warszawie, trwały już wtedy starania o zatwierdzenie statutu Federacji. Konferencja Episkopatu Polski zatwierdziła statut i erygowała oficjalnie Federację FIDES 18 marca 1995 roku. W statucie cel Federacji określony jest szeroko jako:

usprawnianie działalności polskich bibliotek kościelnych, wdrażanie postępu technicznego, a w szczególności komputeryzacja prac bibliotecznych (Art. 6),

natomiast w kolejnym artykule wymienionych jest dziesięć środków, służących do jego osiągnięcia, i wszystkie one mówią o komputeryzacji ${ }^{6}$. W Statucie nie ma zaś w ogóle mowy o innych formach współpracy bibliotek. Wyraźnie

${ }^{6}$ „Mając na względzie szerokie oddziaływanie słowa drukowanego na wychowanie, kształtowanie postaw osobistych i rozszerzanie orędzia ewangelicznego, dla zapewnienia skutecznych środków dla rozszerzania tego oddziaływania, Federacja realizuje swe cele poprzez:

a) prowadzenie działalności badawczej i studiów nad zastosowaniem nowych technik w pracach bibliotecznych;

b) koordynację prac nad komputeryzacją prac bibliotecznych;

c) tworzenie i administrowanie komputerową, ogólnopolską siecią bibliotek kościelnych;

d) tworzenie użytecznych standardów przy komputeryzacji czynności bibliotecznych; 
widać tu zamysł ks. K. Goneta, aby federacja miała charakter specjalistyczny. Najbardziej przyszłościowo brzmi trzeci punkt tego artykułu: „tworzenie i administrowanie komputerową, ogólnopolską siecią bibliotek kościelnych”, w którym ponownie pojawia się główna idea twórcy FIDES.

W związku z decyzją Konferencji Episkopatu, zatwierdzającą statut, kolejne spotkanie bibliotek FIDES 20 czerwca 1995 roku w WMSD w Warszawie miało już charakter Walnego Zgromadzenia Członków Federacji. Wydarzenie to kończy początkowy okres istnienia FIDES.

\section{Osiągnięcia FIDES w dziedzinie komputeryzacji}

Nie zamierzam tu znowu szczegółowo omawiać historii kolejnych dwudziestu lat działalności FIDES, ponieważ są one również dokładnie opisane ${ }^{7}$. Chciałbym natomiast pokazać, jak konsekwentnie federacja zmierzała do osiągnięcia zakreślonego celu, pomimo braku środków i zainteresowania ze strony kościelnych środowisk naukowych. Cały czas starano się nadążać za postępem technicznym i rozwojem narzędzi informatycznych, inicjując nowe rozwiązania i stwarzając nowe możliwości współpracy. Trzeba też zauważyć, że wciąż chodziło o cel nadrzędny komputeryzacji: zaspokojenie potrzeb informacyjnych użytkowników bibliotek kościelnych, umożliwienie im szerokiego i łatwego dostępu do informacji katalogowej i bibliograficznej.

Jak wspomniano, federacja od początku nabrała charakteru konsorcjum bibliotek używających systemu MAK, jakkolwiek nie był to warunek konieczny przynależności do FIDES i niektóre biblioteki pozostały przy swoich rozwiązaniach bądź przeszły na inne systemy. Czterem bibliotekom kościelnym udało się skorzystać z grantu fundacji Mellona i dołączyły do konsorcjum VTLS bądź Horizon (KUL, PAT, PWT w Poznaniu i WSD w Łodzi) ${ }^{8}$. Były też i takie biblioteki, które z tego powodu zrezygnowały z członkowstwa. Jednak łącznie

e) pomoc poszczególnym bibliotekom we wdrażaniu systemu komputerowego i innych form unowocześnienia ich pracy;

f) stymulowanie prac nad tworzeniem komputerowych bibliografii i katalogów piśmiennictwa teologicznego i nauk pokrewnych;

g) szkolenia pracowników bibliotek w zakresie pracy w systemie komputerowym oraz innych nowoczesnych metod pracy;

h) obligatoryjną wymianę informacji między członkami o stanie prowadzonych indywidualnie prac nad komputeryzacją;

i) popularyzację doświadczeń prowadzoną w formie spotkań, konferencji i działalności wydawniczej;

j) zdobywanie środków materialnych na działalność własną oraz wspieranie działań poszczególnych bibliotek i osób prawnych, do których one należą, mających na celu indywidualne uzyskiwanie środków na komputeryzację i wdrażanie postępu technicznego." (Art. 7) - Statut Federacji Bibliotek Kościelnych FIDES, „Fides. Biuletyn Bibliotek Kościelnych”, 1/2 (2000) s. 31-32.

${ }^{7}$ K. Gonet, To już 17 lat! Przeszłość i plany na przyszłość Federacji Bibliotek Kościelnych FIDES, ABMK, 91 (2009) s. 15-23; J. Witczak, Federacja Bibliotek Kościelnych FIDES po dwudziestu latach, „Bibliotekarz”, 7/8 (2013) s. 12-17.

${ }^{8}$ Por. J. Witczak, Biblioteki FIDES w sieci (komputerowej), „Fides. Biuletyn Bibliotek Kościelnych", 1 (1995) s. 55-58. 
w ponad osiemdziesięciu bibliotekach kościelnych na ponad sto, które przewinęly się przez federację, został wdrożony jednolity program MAK, pracujący w jednolitym formacie, umożliwiającym wymianę danych. Dopiero zaniechanie prac nad rozwojem MAK przez Bibliotekę Narodową i ostateczne zaprzestanie jego dystrybucji z dniem 1 stycznia 2013 roku, zmusiło biblioteki FIDES do szukania innych rozwiązań, o czym będzie mowa w trzeciej części opracowania.

Zgodnie z zakreślonym programem działania, od samego początku rozpoczęło się tworzenie katalogów centralnych - osobno książek i prac dyplomowych - najpierw poprzez prostą kumulację offline nadsyłanych na dyskietkach danych, a od 2001 roku dane były częściowo scalane automatycznie z dołączeniem siglów bibliotek. Katalog centralny został udostępniony w Internecie już w 1993 roku, początkowo gościnnie, a następnie z własnego serwera FIDES. Od 1994 roku katalog centralny był rozprowadzany do bibliotek kościelnych w całej Polsce również na płytach CD i stał się też pomocą do kopiowania gotowych opisów dla bibliotek rozpoczynających komputeryzację. Od tego czasu aż do 2005 roku bazy w postaci CD-ROM wydawane były co roku, od 2001 roku wyposażone w interfejs graficzny w postaci programu MAKWWW. Ostatnia wersja centralnego katalogu książek z 2005 roku liczyła 470.742 opisy z 30 bibliotek, zaś baza FIDES-Magister 29.419 opisów z 22 bibliotek.

Jednak tworzony i udostępniany w wyżej opisany sposób katalog centralny nigdy nie był rzeczywiście aktualny. Dlatego w 2004 roku katalog centralny został zastąpiony „katalogiem rozproszonym”, czyli multiwyszukiwarką FIDKAR, działającą przy pomocy protokołu Z39.50. Oprogramowanie potrzebne do jej uruchomienia w całości zostało napisane na zamówienie Federacji FIDES. W szczytowym okresie swojego istnienia FIDKAR FIDES oferował użytkownikom wyszukiwanie w niemal stu bazach różnego typu, w tym około połowy online. Niewątpliwie to rozwiązanie było dużym krokiem naprzód i dobrze służyło zarówno bibliotekarzom, ułatwiając katalogowanie, jak i użytkownikom, poszukującym aktualnej informacji. Po upływie z górą dziesięciu lat FIDKAR znów staje się powoli rozwiązaniem przestarzałym. Pojawiły się nowe możliwości współpracy i realnego współkatalogowania, a samo oprogramowanie też nie jest rozwijane. Aktualnie do FIDKARA podłączone są 33 pojedyncze katalogi bibliotek, w tym jeden spoza FIDES (PWT w Poznaniu), oraz dwa centralne (FIDES i dominikański). Podłączonych jest online $20 \mathrm{z}$ nich, a pozostałe udostępniane z serwera FIDES.

Celem równie ważnym jak tworzenie katalogu centralnego było dla ks. K. Goneta i FIDES opracowywanie komputerowych bibliografii piśmiennictwa teologicznego i nauk pokrewnych (por. Art. 7f Statutu). Od początku zatem poszczególne biblioteki członkowskie podjęły się tworzenia baz bibliograficznych zawartości czasopism, wydawanych w ich ośrodkach teologicznych. Po kumulacji wchodziły one w skład serwisu centralnego na stronie WWW i na CD-ROM. Ostatnia wersja z 2005 roku bazy „Bibliografia Nauk Kościelnych (fragment)” liczyła 37.709 opisów i stanowiła połączenie 17 baz bibliograficznych o różnym zakresie i zasięgu, tworzonych przez biblioteki należące do Federacji. W następnym kroku bazy bibliograficzne zostały podłączone do multiwyszukiwarki FIDKAR, podobnie jak 
bazy katalogowe. Oba rozwiązania były bardzo niedoskonałe z powodu braków co do zakresu i kompletności oraz z powodu niejednolitości opracowania.

W 2011 roku udało się rozwiązać ten problem braku jednej, spójnej i w miarę kompletnej bibliografii nauk kościelnych, której utworzenie federacja postulowała od wielu lat. Dzięki nawiązaniu współpracy z Biblioteką Narodową rozpoczęła się realizacja projektu pod nazwą Elektroniczna Bibliografia Nauk Teologicznych (EBNT). Biblioteka Narodowa zobowiązała się udostępnić nieodpłatnie opisy bibliograficzne tworzone w Zakładzie Bibliografii Zawartości Czasopism, zarówno zawarte w istniejących już bazach BZCZ z lat 1996-2011, jak i nowo dodawane w cyklu miesięcznym. Bibliografia obejmuje głównie zawartość publikacji wydawanych przez uczelnie kościelne i wydziały teologiczne, począwszy od roku 1980. Nowością jest połączenie w jednej bazie bibliografii zawartości czasopism z zawartością prac zbiorowych, takich jak księgi jubileuszowe i materiały konferencyjne. Są one tworzone przez biblioteki FIDES, podobnie jak opisy bibliograficzne zawartości wcześniejszych roczników oraz tytułów czasopism, nieopracowanych przez Bibliotekę Narodową. Wykorzystano - po konwersji na format MARC21 - istniejące cząstkowe bazy bibliograficzne FIDES. Federacja dokonała też ujednolicenia opisów otrzymanych od BN oraz wzbogaca je m.in. o abstrakty i odnośniki internetowe oraz tytuły streszczeń obcojęzycznych. W celu ujednolicenia haseł autorskich dokonywana jest wspomagana komputerowo ich wymiana na hasła $z$ kartoteki wzorcowej NUKAT. W ten sposób EBNT stała się jedną z pierwszych w Polsce, które korzystają w pełni z CKHW NUKAT. W opracowaniu przedmiotowym wykorzystywany jest język haseł przedmiotowych Biblioteki Narodowej.

Początkowo baza EBNT była opracowywana w programie MAK i udostępniana w programie MAK WWW z serwera FIDES. W listopadzie 2014 roku została przeniesiona do systemu Koha. Zapewnia on pełną obsługę kartotek wzorcowych i możliwość wprowadzania danych z wielu lokalizacji w Polsce, co jest bardzo pożądane z punktu widzenia Federacji FIDES. W ten sposób poszczególne biblioteki mogą współtworzyć EBNT online. Z punktu widzenia czytelnika w Koha można uzyskać inną jakość wyszukiwania, w tym również fasetowe zawężanie wyników. Wydaje się, że ostatnie zmiany w Języku Haseł Przedmiotowych BN - przejście na opis przy pomocy Deskryptorów BN - znajdą doskonałe zastosowanie w tego typu wyszukiwaniu. W lutym 2015 roku statystyka Elektronicznej Bibliografii Nauk Teologicznych prezentuje się następująco: łącznie 98.766 rekordów, w tym 15.980 (16\%) autorstwa bibliotek FIDES, indeksowanych 201 tytułów czasopism i 501 prac zbiorowych (10.043 rekordów).

Uzupełnieniem prac nad komputeryzacją bibliotek i zaspokajaniem potrzeb informacyjnych czytelników stało się utworzenie własnej biblioteki cyfrowej Federacji FIDES. Uroczyste uruchomienie Księgozbioru Wirtualnego Federacji Bibliotek Kościelnych FIDES miało miejsce 27 września 2006 roku, w 15. rocznicę utworzenia Federacji. Warto zauważyć, że znowu wtedy znajdowaliśmy się w czołówce - było to dziesiąte $\mathrm{z}$ kolei wdrożenie systemu dLibra w Polsce. Biblioteka cyfrowa została pomyślana jako platforma, na której zarówno instytucje kościelne, jak i indywidualni autorzy mają możliwość publikowania swoich 
utworów. O jej zawartość miały się też troszczyć biblioteki członkowskie, dostarczając zdigitalizowane obiekty do publikacji. Ze względu na słabość bibliotek członkowskich Federacji FIDES i z braku środków na digitalizację, oczekiwania związane $\mathrm{z}$ uruchomieniem biblioteki cyfrowej nie w pełni zostały zrealizowane i wciąż posiada ona niewielką relatywnie zawartość.

Warto dodać, że w latach 2001-2009 istniało powołane przez FIDES Biuro ds. Rozwoju i Komputeryzacji, którego jedynym pracownikiem był ks. K. Gonet, wykonujący swą pracę bez wynagrodzenia ze strony federacji, a utrzymujący się częściowo z prowadzonej działalności gospodarczej. Biuro wykonywało prace serwisowe programu MAK, prowadziło szkolenia, współpracowało z Biblioteką Narodową w rozwijaniu pakietu MAK, prowadziło udane starania o dotacje z Ministerstwa Nauki i Szkolnictwa Wyższego, koordynowało prace nad tworzeniem Tezaurusa Nauk Kościelnych i rozpoznawało kierunki rozwoju komputeryzacji bibliotek, wdrażając nowe rozwiązania. Niestety, w czerwcu 2009 roku założyciel FIDES zrezygnował całkowicie z dotychczasowej aktywnej działalności na rzecz komputeryzacji bibliotek kościelnych. Od siedmiu lat wdrażaniem kolejnych projektów i obsługą centralnego serwisu informacji katalogowej i bibliograficznej Federacji FIDES zajmują się inne osoby.

\section{Aktualny stan komputeryzacji bibliotek należących do FIDES}

Na początku jubileuszowego 2016 roku do FIDES należy 85 bibliotek, w tym 4 parafialne. Jak przedstawia się ich skomputeryzowanie? Jeśli chodzi o używane systemy, to nadal króluje MAK - łącznie 49 bibliotek, w tym 24 online z własnych serwerów, 13 z serwera FIDES, a 12 tylko lokalnie. Systemu Koha używa 16 bibliotek, w tym 12 wspólnie - o czym poniżej. Kolejne miejsca zajmują: Prolib - trzy biblioteki, Virtua - dwie, Aleph, Horizon, Symphony, Patron - po jednej. Dwie biblioteki używają własnych rozwiązań, w tym Biblioteka "Ignatianum” w Krakowie. W dziewięciu bibliotekach nie ma prawdopodobnie w ogóle katalogu komputerowego, w tym niestety w tak ważnej bibliotece, jaką jest Biblioteka WSD w Płocku. Do FIDES nie należą obecnie biblioteki pięciu diecezji (trzy z nich na początku uczestniczyły w pracach) - trzy udostępniają katalog online w programach Mol/Libra, Horizon i Koha 2.25, jedna używa MAK-a lokalnie, natomiast Biblioteka Diecezjalna w Zamościu nie jest jeszcze skomputeryzowana. Komputeryzacja bibliotek zakonnych spoza federacji nie była badana.

Jak widać z powyższego, rozpoczął się już w bibliotekach kościelnych proces zmiany oprogramowania. Sprawa programu bibliotecznego, który zastąiłby zasłużonego MAK-a, stanowiła przedmiot zatroskania zarządu FIDES od momentu przerwania przez Bibliotekę Narodową prac nad wersją $5.0 \mathrm{~W}$ architekturze klientserwer. Analizowana była możliwość zastosowania dla całej federacji któregoś z krajowych systemów, ze względu na ich niższe ceny. Nie ulegało też wątpliwości, że należy zmienić koncepcję i przejść na model współkatalogowania z jedną centralną bazą rekordów wzorcowych. Taki model przyjęto w systemie MAK+ i w innych krajowych systemach przeznaczonych głownie dla bibliotek publicznych. Jednak ich zasób bibliograficznych rekordów wzorcowych, nie odpowiadający w znacznym stopniu zasobom literatury teologicznej polskiej i obcej w biblio- 
tekach kościelnych, stanowił jedną z najpoważniejszych przeszkód w skorzystaniu z oferowanych rozwiązań.

Opatrznościowo w 2010 roku za sprawą o. Janusza Kaczmarka OP pojawiła się polska implementacja systemu Koha w wersji społecznościowej, która została zastosowana przez niego do utworzenia katalogu bibliotek dominikańskich na bazie katalogu Biblioteki Kolegium Filozoficzno-Teologicznego Dominikanów w Krakowie. Po okresie analiz i ustaleń przyjęte zostało dla FIDES właśnie to rozwiązanie i 14 czerwca 2014 roku uruchomiony został Centralny Katalog Bibliotek FIDES po zaimportowaniu z katalogu Biblioteki PWT i MWSD we Wrocławiu, prowadzonego w systemie MAK, 91.214 rekordów bibliograficznych oraz danych czytelników i historii wypożyczeń. Założenia projektu są następujące:

1. Katalog centralny utrzymywany w systemie Koha i umieszczony na serwerze FIDES

2. Wspólna, ujednolicona baza rekordów bibliograficznych (jeden opis - wiele zasobów)

3. Wspólny interfejs prezentacji danych bibliograficznych

4. Wspólny mechanizm wypożyczalni (ale odrębni czytelnicy) i wsparcie dla wypożyczeń międzybibliotecznych

5. Opracowanie formalne zgodne z kartoteką haseł wzorcowych NUKAT

6. Opracowanie rzeczowe zgodne z kartoteką Języka Haseł Przedmiotowych BN 7. Włączenie katalogu do NUKAT, co oznacza obligatoryjne podjęcie współpracy czynnej bądź biernej bibliotek członkowskich z Centrum NUKAT

8. Projekt ma być samofinansujący się, na niezbędne prace informatyczne - stałe utrzymanie katalogu oraz na wynagrodzenie dla bibliotekarza systemowego biblioteki członkowskie będą wpłacać miesięcznie ustaloną składkę na konto FIDES.

Do chwili obecnej do katalogu wspólnego zostały przeniesione katalogi 12 bibliotek, w tym 10 z systemu MAK, jedna z Horizona (Biblioteka Towarzystwa Chrystusowego z Poznania) a jedna biblioteka rozpoczęła katalogowanie od zera. Proces migracji składa się z następujących etapów:

1. sprawdzenie i korekta błędów formalnych oryginalnych rekordów

2. ewentualna konwersja do formatu MARC21

3. dołączenie skonwertowanego katalogu do katalogu wspólnego

4. automatyczna wymiana rekordów (tam, gdzie to możliwe) na rekordy NUKAT

5. dla pozostałych rekordów automatyczne przygotowanie listy możliwych wymienników na rekordy NUKAT bądź już istniejące w bazie i ręczne podejmowanie decyzji o wymianie

6. konsolidacja dubletów pojawiających się na etapie wymiany

7. wygenerowanie i konsolidacja z CKHW haseł formalnych i niektórych przedmiotowych występujących w rekordach, które nie zostały wymienione.

Łącznie w katalogu znajduje się aktualnie9 niemal 302.000 rekordów bibliograficznych, z których ponad 173.000 to rekordy pobrane z katalogu NUKAT (57,4\%), i ponad 757.000 rekordów egzemplarza. Poszczególne biblioteki wymie-

\footnotetext{
${ }^{9}$ Według stanu na dzień 29 lutego 2016 roku.
} 
nily na rekordy NUKAT od $58 \%$ do $90 \%$ swoich rekordów a scalanie i wymiana trwają permanentnie, zwłaszcza w odniesieniu do wydawnictw wielotomowych.

Bardzo ważnym efektem uruchomienia wspólnego katalogu w Koha jest możliwość nawiązania współpracy z Centrum NUKAT przez biblioteki FIDES, używające do tej pory systemu MAK. Są to wszystko biblioteki naukowe o bogatych księgozbiorach, ale z niewielką liczbą pracowników, czasem wręcz jednoosobowe. W przyjętym scentralizowanym rozwiązaniu nie muszą się one troszczyć ani o sprzęt, ani o skomplikowaną obsługę informatyczną komunikacji z katalogiem NUKAT, ponieważ dla całości wystarcza jeden informatyk i jeden serwer. Spośród dwunastu bibliotek uczestniczących obecnie w projekcie już sześć podjęło czynną współpracę z NUKAT i od 17 lipca 2014 roku (dodanie pierwszego symbolu WR_194 do katalogu NUKAT) utworzyły one łącznie 3.375 rekordów bibliograficznych i 1.763 rekordy khw.

W ten sposób w ostatnim roku znacząco wzrosła liczba bibliotek kościelnych należących do Federacji FIDES, które współpracują z katalogiem centralnym NUKAT. Do takich bibliotek, jak BU KUL i UPJPII, od początku współtworzących NUKAT, oraz Biblioteki WSD w Łodzi i Biblioteki Diecezjalnej w Toruniu używających dużych systemów, jak również dwóch bibliotek dominikańskich, dołączyło 14 nowych dzięki przejściu na system Koha - 12 we wspólnym projekcie FIDES i dwie, które są na etapie samodzielnego wdrażania (UKSW i „Bobolanum”). Łącznie do NUKAT należy zatem już aż 20 bibliotek FIDES oraz jedna za pośrednictwem swojej biblioteki głównej (Wydział Teologiczny UŚ w Katowicach). Ponadto z NUKAT współpracuje biernie Biblioteka Wyższej Szkoły Filologii Hebrajskiej w Toruniu, prowadzona przez Prowincję św. Franciszka z Asyżu Zakonu Braci Mniejszych Franciszkanów. Dzięki współpracy z NUKAT znacznej grupy bibliotek kościelnych mogą one teraz w większym stopniu odnosić korzyści ze współkatalogowania specyficznej literatury teologicznej i religijnej, a z drugiej strony wzbogacają one w ten sposób zasoby informacyjne katalogu NUKAT o tego rodzaju literaturę. Zarazem obecność w centralnym katalogu bibliotek naukowych jest niezwykle ważną promocją bibliotek kościelnych i ich zbiorów. Warto wspomnieć również o korzyściach, jakie z uczestnictwa we wspólnym projekcie odnoszą bibliotekarze - podnoszą swoje kompetencje przez kontakt z innymi bibliotekami i bibliotekarzami kościelnymi, zarówno na etapie wdrażania, jak i potem, na etapie współpracy, oraz przez uczestnictwo w NUKAT - ustawiczne szkolenia, współkatalogowanie, przepływ informacji etc.

Można więc powiedzieć, że zaczął się nowy etap komputeryzacji bibliotek kościelnych i znany jest jej docelowy model na tym etapie. Jednak - jak widać z liczby bibliotek nadal używających programu MAK - przed FIDES jeszcze długa droga do osiągnięcia celu. Specjaliści zapewniają, że Koha potrafi obsłużyć dużo większą liczbę bibliotek, natomiast obawy budzi strona organizacyjna tak dużego przedsięwzięcia. Niepokoi również to, że nie ma obecnie „kolejki” bibliotek, chcących przejść z MAK-a do wspólnego katalogu. Nie wydaje się jednak, żeby istniała inna ścieżka, uzasadniona ekonomicznie i organizacyjnie, która prowadziłaby do porównywalnych efektów, i czekanie nic tu nie da, bo jak mówiła w 1987 roku Maria Wrocławska: 
Stoimy w miejscu, a to znaczy, że cofamy się w stosunku do szybkiego postępu w innych krajach i stajemy się bezradni wobec eksplozji informacji w świecie [...]. Nie możemy bowiem dopuścić, aby przyczyna opóźnień i zacofania tkwiła w nas samych ${ }^{10}$.

Słowa kluczowe: Federacja Bibliotek Kościelnych FIDES, biblioteki kościelne, komputeryzacja, katalog centralny, informacja naukowa

\section{BIBLIOGRAFIA}

Gonet Krzysztof, Komputeryzacja bibliotek $i$ możliwości jej wplywu na procesy gromadzenia księgozbiorów w bibliotekach kościelnych: zarys problematyki, „Archiwa Biblioteki i Muzea Kościelne”, 62 (1993) s. 255-268.

Gonet Krzysztof, To już 17 lat! Przeszłość i plany na przyszłość Federacji Bibliotek Kościelnych FIDES, „Archiwa Biblioteki i Muzea Kościelne”, 91 (2009) s. 15-23.

Wójtowicz Marta, Federacja Bibliotek Kościelnych FIDES w Polsce w latach 1991-2001: (10-lecie istnienia Federacji FIDES), „Fides. Biuletyn Bibliotek Kościelnych”, 16/17 (2003) z. 1/2, s. 21-72.

Statut Federacji Bibliotek Kościelnych FIDES, „Fides. Biuletyn Bibliotek Kościelnych”, 10-11 (2000) z. 1/2, s. 30-40.

Witczak Jerzy, Biblioteki FIDES w sieci (komputerowej), „Fides. Biuletyn Bibliotek Kościelnych", 1 (1995) s. 55-58.

Witczak Jerzy, Federacja Bibliotek Kościelnych FIDES po dwudziestu latach, „Bibliotekarz", 7/8 (2013) s. 12-17.

Wrocławska Maria, Możliwości komputeryzacji biblioteki, „Archiwa Biblioteki i Muzea Kościelne”, 56 (1988) s. 147-156.

\section{YEARS OF THE COMPUTERIZATION OF CHURCH LIBRARIES IN POLAND-THE ACHIEVEMENTS OF THE FEDERATION FIDES}

\section{Summary}

This article outlines the origins of the Federation of Church Libraries FIDES with particular emphasis on the purpose for which it was created, i.e. the computerization of libraries and bibliographic information. Then the work presents the implementation of the main objective of the federation within 25 years of its existence. Finally, it focuses on the current state of work on the computerization of church library catalogues in Poland.

Keywords: the Federation of Church Libraries FIDES, church libraries, computerization, the main catalogue, research information

${ }^{10}$ Cyt. za: Gonet, Komputeryzacja bibliotek, s. 256. 